\title{
ASGHAR ALI ENGINEER DAN REFORMULASI MAKNA TAUHID
}

\author{
Muhaemin \\ Dosen Fakultas Ushuluddin dan Filsafat \\ UIN Alauddin Makassar \\ E-mail: $\underline{\text { muhaeminlatif@gmail.com }}$ \\ 08114114845
}

\begin{abstract}
This paper examines the notion of Asghar Ali Engineer's view on tauhid. Engineer is one of the leading thinkers as well as an activist who was not only generating the ideas of rethinking but also involved in a variety of activities relating to reformation of Islamic thought. This employs qualitative research through collecting datas and information from different manuscripts, books, and journals. The main objective of this research is demonstrating the urgency of reformulating the meaning of tauhid. The finding suggests that tauhid is the core of Islamic teaching. It is the basic tenet of any religions that may generate a power to liberate human being from any kind of discrimination. In other words, tauhid is an energy that can guide mankind released from ignorance, oppression and poverty. Tauhid not only concerned on the unity of God but also the oneness of society. Classless society is the ultimate goal of tauhid that lead to set the people on the same position before the God.
\end{abstract}

\section{Keywords:}

Tauhid, Reformulate, Discrimination, Classless Society

\section{A. Latar belakang}

Sosok Asghar Ali Engineer (1939-2013) -selanjutnya disebut Engineer- dalam barisan pembaharu pemikiran Islam perlu menjadi kajian serius bagi dunia akademik. Engineer tidak hanya hadir sebagai pemikir yang sibuk mengampanyekan pentingnya reformulasi ajaran Islam, tetapi ia sekaligus menjadi aktivis yang telah melibatkan diri dalam berbagai forum dan gerakan pembaharuan dalam pemikiran Islam. Ia merupakan avant garde intelektual muslim yang berasal dari Bombay, India, yang serius mengampanyekan sekaligus membumikan teologi ke dalam dunia praksis. Sebagai aktivis, ia menjadi anggota salah satu kelompok Syiah Ismailiyah, Daudi Bohras (Guzare Daudy). ${ }^{1}$ Engineer oleh Michael Amalados dimasukkan dalam deretan tokoh

\footnotetext{
${ }^{1}$ Penjelasan lebih lanjut tentang Daudi Bohras, Engineer mengulas dalam bukunya yang berjudul The Bohras: Study of the Bohra (or Ismailite) Community in India, (1980). Memahami kelompok Daudi Bohras ini menjadi penting jika ingin memetakan pemahaman keagamaan Daudi Bohras. Dalam catatan pengantar Djohan Effendi dalam buku Engineer, Islam dan Pembebasan, ia mengatakan bahwa Daudi Bohras dipimpin oleh Imam sebagai pengganti Nabi yang dijuluki Amirul Mukminin. Mereka mengenal 21 orang Imam. Imam mereka yang terakhir Mawlana Abu al-Qasim al-Thayyib yang menghilang pada tahun $526 \mathrm{H}$. Namun mereka percaya bahwa ia masih hidup hingga sekarang. Kepemimpinannya kemudian dilanjutkan oleh para da'i (terma ini kemudian yang menginspirasi terma Daudi) yang selalu berhubungan dengan Imam terakhir. Untuk menjadi da'i diperlukan 94 kualifikasi yang diringkas menjadi
} 
intelektual di Asia yang menjadi pelopor teologi pembebasan dalam konteks agama Islam. Engineer selevel dengan Abu A'la Maududi (1903-1979) dan Ali Shariati (19331977). ${ }^{2}$ Engineer meyakini bahwa agama Islam adalah jalan pembebasan yang ia istilahkan sebagai religiositas yang senantiasa menyatakan keterlibatan emosi yang tulus dengan visi moral dan spiritual yang menunjuk kepada pengalaman manusia yang agung untuk memperjuangkan harkat kemanusiaannya. Menurutnya, tauhid adalah pengakuan terhadap perlunya memperjuangkan secara serius problem bipolaritas spiritual-material kehidupan manusia dengan menyusun kembali tatanan sosial sekarang dengan cara yang lebih baik, lepas dari sifat eksploitatif, adil dan egaliter. ${ }^{3}$ Barangkali ini yang menjadi alasan Engineer mengapa ia lebih cenderung menyebut teologi dibandingkan kalam pembebasan karena sifat progresivitas dan revolusioner dari makna teologi itu sendiri.

Sebagai seorang aktivis sekaligus pemikir, Engineer memang berbeda dengan pemikir muslim lain yang lebih banyak berkutat pada tataran wacana seperti Mohammed Arkoun (1928-2010) yang berusaha membongkar rancang bangun pemikiran Islam dengan menawarkan pisau analisa hermeneutik historis. ${ }^{4}$ Begitupula ia berbeda dengan Mohammad Shahrur (1.1938), seorang intelektual muslim dari Syria yang menawarkan gagasan pembacaan baru terhadap al-Qur'an. ${ }^{5}$ Engineer juga berbeda dengan Hassan Hanafi (1.1935) di Mesir yang terkenal dengan gagasan al-yasar alIslami (Kiri Islam) yang menulis karya monumental minal aqīdah ila al-thaurah (dari teologi ke revolusi) sebanyak 5 jilid. ${ }^{6}$ Selain itu ia berbeda dengan Ziaul Haque yang menulis buku yang sedikit provokatif, Revelation and Revolution in Islam (wahyu dan

4; 1. Pendidikan, 2. Administratif, 3. Moral dan teoretikal, 4. Kualifikasi keluarga dan kepribadian. Menariknya, di antara kualifikasi itu, seorang da'i harus tampil sebagai pembela umat yang tertindas dan berjuang melawan kedhaliman. Di sinilah posisi Asghar Ali Engineer menjadi penting karena ia adalah seorang da'i dan sekaligus pemimpin dari kelompok Daudi Bohras.

${ }^{2}$ Lihat Michael Amaladoss, Life in freedom: Liberation Theologies from Asia, diterjemahkan oleh A Widyamartala dan Cinderalas, Teologi Pembebasan Asia, h. 216-247.

${ }^{3}$ Asghar Ali Engineer, Islam and Its Relevance to Our Age, diterjemahkan oleh Hairus Salim HS dan Imam Baehaqy, Islam dan Pembebasan (Yogyakarta: LKiS, 1993), h. 80.

${ }^{4}$ Lihat Muhaemin Latif, Islamologi Terapan: Membongkar Bangunan Pemikiran Islam ala Mohammed Arkoun (Cet. I; Makassar: Alauddin University Press, 2012)

${ }^{5}$ Muhammad Shahrur, al-Kitab wa al-Qur'an; Qirāah Muashirah (Damaskus: al-Ahali alThibaah, 1990).

${ }^{6}$ Sebenarnya secara teoretis, apa yang dieksplorasi oleh Hassan Hanafi adalah bentuk pencarian energi pembebasan dalam turats Islam. Turats tidak hanya sekedar warisan ilmu pengetahuan masa lampau, tetapi ia juga bisa menjadi pendobrak energi progresif dan pendobrak tentang kesadaran berpikir dan berprilaku. Hassan Hanafi menyebut turats sebagai penjaga gerbang dan pelestari "anarkisme". Dalam anarkisme terkandung semangat revolusi pembebasan dan menjadi pendorong perubahan sosial menuju masyarakat egaliter dan demokratis, terbebas dari belenggu otoritarianisme. Bahkan gerakangerakan anti globalisasi adalah produk dari anarkisme yang di dalamnya terkandung energi pembebasan. Lihat Hassan Hanafi, Dirāsah Islamiah, diterjemahkan oleh Miftah Faqih, Islamologi I: Dari Teologi Statis ke Anarkis, (Yogyakarta: LKiS, 2004). Hanya saja, sejauh penelusuran penulis, ide pembebasan dari Hassan Hanafi masih berkutat pada tataran teoretis. Hassan Hanafi sendiri tidak pernah menyebut dalam bukunya teologi pembebasan sebagaimana Asghar Ali Engineer. 
revolusi dalam Islam). ${ }^{7}$ Penulis melihat gaya pemikiran Engineer mirip dengan Sayyid Quthb $^{8}$ dengan revolusi Islamnya dan Ali Syariati dengan ide pemberontakannya.

Mengingat kompleksitas pemikiran Engineer, artikel ini akan berfokus pada makna tauhid yang telah direformulasi menjadi sebuah gerakan. Sebelum berbicara lebih jauh postur pemikirannya, ada baiknya menyimak potret kehidupan intelektual Engineer yang memengaruhi pemikirannya secara umum.

\section{B. Riwayat Hidup dan Karir Intelektual Asghar Ali Engineer}

Asghar Ali Engineer lahir pada tanggal 10 Maret 1939 di Salumbar, ${ }^{9}$ Rajashtan, India. Asghar Ali Engineer berasal dari keluarga Bohras yang merupakan sekte dari Syiah Ismailiyah. Di antara beberapa sekte Syiah Ismailiyah, Daudi Bohras termasuk memiliki banyak pengikut yang diperkirakan sekitar 1 juta pengikut yang tersebar di berbagai dunia Islam. Hanya saja, mayoritas pengikutnya berada di India, termasuk keluarga Asghar Ali Engineer. ${ }^{10}$ Ayah Engineer adalah Syeikh Qurban Husain, salah seorang ulama dan pemimpin Dawoodi Bohras, dan ibunya bernama Maryam. Meskipun Bohras termasuk sekte yang beraliran ekstrem-fundamental, tidak demikian dengan ayah Engineer. Ia lebih dikenal sebagai ulama liberal, terbuka, dan berpikiran inklusif terutama ketika melakukan diskusi-diskusi dengan kelompok yang berbeda aliran atau agama. ${ }^{11}$ Hal ini diakui sendiri oleh Engineer dalam testimoninya yang tertuang dalam artikelnya berjudul What I believe sebagaimana berikut:

...My father, who was firm believer in the Shi'ah-Isma'ili Islam had somewhat open mind and showed great patience when persons of other persuasions entered into dialogue with him. In my childhood a Hindu Brahmin priest used to come and have dialogue with my father and both used to exchange views on each others beliefs. But otherwise my father was firm in his own beliefs. I was brought up in this religious environment... 12

Kutipan di atas mengilustrasikan bahwa sejak kecil Engineer sudah mendapatkan pendidikan pluralisme dari lingkungan keluarganya, terutama dari ayahnya sendiri. Tentu saja, atmosfer tersebut pada gilirannya akan membentuk postur

\footnotetext{
${ }^{7}$ Johan Effendi, "Memikirkan Kembali Asumsi Pemikiran Kita” Kata Pengantar buku Asghar Ali Engineer, Islam and Its Relevance to Our Age, diterjemahkan oleh Hairus Salim HS dan Imam Baehaqy, Islam dan Pembebasan (Yogyakarta: LKiS, 1993), h. v-vi.

${ }^{8}$ Sayyid Quthb, Islam: the Misunderstood Religion, diterj. oleh Fungky Kusnaedy Timur, Islam Agama Pembebas (Yogyakarta: Mitra Pustaka; 2001), h. 232.

${ }^{9}$ Salumbar adalah salah satu kota di Kabupaten Udaipur, Provinsi Rajashtan. Populasi penduduk Kota Salumbar terbilang tinggi. Data statistik 2001, populasi Salumbar sebanyak 15682 dengan persentase $51 \%$ laki-laki dan $49 \%$ perempuan. Kota ini termasuk bekas jajahan Inggris

${ }^{10}$ Mohammad Imran Mohamed Taib, "Religion, Liberation and Reforms: An Introduction to the Key Thoughts of Asghar Ali Engineer”, h. 3.

${ }^{11}$ M. Agus Nuryatno, “Asghar Ali Engineer's Views on Liberation Theology and Womens Issues in Islam", h. 5.

${ }^{12}$ Asghar Ali Engineer, "what I believe",http://anromeda.rutgers.edu/ (diakses pada tanggal 27 Februari 2015).
} 
pemikiran Engineer yang lebih inklusif dan apresiatif terhadap perbedaan-perbedaan yang ada baik dari segi agama, budaya dan bangsa.

Sebagaimana anak pada umumnya, Engineer kecil juga memulai pendidikannya pada sekolah-sekolah negeri yang mengajarkan pengetahuan sekuler modern. Ia menyelesaikan pendidikannya dari tingkat SD (Sekolah Dasar) sampai dengan SMA (Sekolah Menengah Atas) pada sekolah yang berbeda-beda, seperti Hosanghabad, Wardha, Dewas dan Indore. Selain itu, Engineer kecil juga mendapatkan pendidikan agama dari ayahnya sendiri seperti bahasa Arab, tafsir, kitab suci al-Qur'an, hadis dan fiqih. ${ }^{13} \mathrm{Hal}$ ini wajar, karena ayah Engineer adalah seorang ulama yang menguasai berbagai bidang ilmu agama sehingga bisa mengajar Engineer dengan mudah. Namun yang menarik adalah dorongan ayah Engineer untuk mempelajari berbagai disiplin ilmu tanpa melakukan pemisahan antara ilmu sekuler modern dan ilmu agama. Kondisi ini sekali lagi mempertegas bahwa lingkungan keluarga Engineer adalah gambaran lingkungan pluralis, inklusif dan moderat.

Setelah menyelesaikan pendidikannya di Salumbar, Engineer kemudian memilih kuliah di Fakultas Teknik Sipil di Vikram University, ${ }^{14}$ Ujjain, Bombay, India pada tahun 1956. Pilihan ini sekali lagi karena mendapat dukungan dari ayahnya yang memintanya untuk melanjutkan kuliah bidang teknik atau kesehatan. ${ }^{15}$ Namun yang menarik adalah tidak adanya permintaan ayahnya kepada Engineer untuk melanjutkan pendidikan tinggi di bidang agama, padahal seperti diketahui bahwa India memiliki universitas Islam yang terkenal seperti AMU (Aligarh Muslim University) yang sudah dibangun sejak tahun 1875 dengan nama Mohammedan Anglo-Oriental College oleh Sir Syed Ahmed Khan. ${ }^{16}$ Selain itu sebagai seorang ulama Bohras tentu memiliki jaringan yang luas dengan perguruan tinggi yang concern di bidang agama baik yang berada di India, maupun yang ada Iran, Mesir, bahkan Mekkah sebagai sentra ilmu agama Islam. Penulis dalam hal ini tidak mengetahui persis atas opsi-opsi pendidikan yang dipilih oleh ayah Engineer yang pada gilirannya akan menentukan masa depan dari Asghar Ali Engineer. Hanya saja, menurut Agus, Engineer disamping mempelajari teknik sipil di bangku perkuliahan, dia tetap menekuni ilmu agama dengan cara

${ }^{13}$ Asghar Ali Engineer, "What I Believe”,http://anromeda.rutgers.edu/ (diakses pada tanggal 28 Februari 2015).

${ }^{14}$ Universitas ini sebenarnya kurang populer di India. Bahkan data yang dikeluarkan web ranking universitas 2015 tentang universitas-universitas terbaik di India, Universitas Vikram tidak termasuk dari 500 universitas terbaik di India. Uraian lebih lanjut, silahkan kunjungi http://www.4icu.org/in/ (diakses pada tanggal 28 Februari 2017). Februari 2015)

${ }^{15}$ Asghar Ali Engineer, "What I Believe", http://anromeda.rutgers.edu/ (diakses pada tanggal 28

${ }^{16}$ Tahun 1920, namanya diubah menjadi Aligarh Muslim University dan mendapatkan status Central University. AMU terletak $130 \mathrm{~km}$ di sebelah Tenggara dari kota Delhi. Universitas ini dibangun dengan mengadaptasi sistem pembelajaran di Universitas Cambridge dan Oxford, Inggris. Sir Syed Ahmed Khan berkeinginan untuk memajukan India, caranya adalah dengan membasmi keterbelakangan masyarakatnya menggunakan pendidikan. Walaupun sistem pendidikan yang diambil berasal dari negara barat, tapi AMU tetap menjaga nilai-nilai kandungan islam sebagai pedoman. Uraian lebih lanjut silahkan kunjungi http://www.berkuliah.com/2014/06/20-universitas-terfavorit (diakses pada tanggal 28 Februari 2015). 
otodidak. ${ }^{17}$ Ilmu-ilmu agama yang diperoleh oleh Asghar Ali Engineer kebanyakan melalui otodidak, tidak melalui pendidikan formal dengan bersekolah di sekolahsekolah agama. Penguasaannya pada beberapa bahasa membuat ia begitu mudah menelaah karya-karya Islam klasik sampai kepada pemikiran filosof-filosof Barat kontemporer. Engineer sendiri, menurut Agus, menguasai bahasa Inggris, Arab, Urdu, Persia, Gujarat, Hindi dan Marathi. ${ }^{18}$ Selain karena modal bahasa, poin penting menurut penulis yang menjadikan Engineer sebagai intelektual yang dikenal dunia Islam dan Barat adalah semangat kecintaan terhadap ilmu pengetahuan serta kegelisahannya terhadap ketertindasan dan kemiskinan yang dialami oleh sebagian besar umat Islam. Agama menurutnya cenderung disalahtafsirkan sehingga kemiskinan dan penindasan dijadikan sebagai takdir yang tidak bisa dihindari oleh umat Islam sendiri. Poin-poin inilah yang memotivasi Engineer untuk terus belajar Islam dengan cara otodidak.

Setelah menyelesaikan pendidikan formalnya di Universitas Vikram dan mendapatkan gelar sarjana dalam bidang teknik sipil, Engineer kemudian bekerja di BUMN India sebagai seorang engineer profesional selama 20 tahun ${ }^{19}$ sebelum akhirnya bergabung pada gerakan reformasi Dawoodi Bohra sekitar tahun 1970an. ${ }^{20}$ Pada tahun 1983, Engineer diberi gelar DLitt ${ }^{21}$ (Ph.D atau Doktor) oleh Universitas Calcutta sebagai gelar penghormatan atas dedikasi dan integritasnya terhadap kemanusiaan dan perdamaian di India. Engineer termasuk intelektual produktif. Dia telah menulis kurang lebih 40 buku dalam berbagai bidang keislaman dan menulis berbagai artikel yang telah dipublikasikan di berbagai penerbit dan website. Sejauh penelusuran penulis, Engineer mulai menulis pikiran-pikirannya kemudian diterbitkan dalam bentuk buku sejak tahun 1980. Buku pertama yang ditulisnya adalah The Bohras. ${ }^{22}$ Buku ini adalah refleksi kritis pemikiran Asghar tentang Bohras dengan berbagai sepak terjangnya. Jika dirunut perjalanan intelektual Engineer sebagai aktivis, sebenarnya berawal ketika ia bergabung pada gerakan Bohras. Poin ini akan dibahas pada uraian selanjutnya. Sejak tahun 1980, perjalanan Engineer sebagai penulis atau intelektual produktif dimulai. Hampir setiap tahun dia menulis buku dalam berbagai aspek pemikiran Islam, bahkan pada tahun-tahun tertentu dia menulis beberapa buku dalam setahun. Meskipun bahasa Inggris bukan bahasa ibu (mother tongue) Engineer, namum sebagian besar tulisan-

\footnotetext{
${ }^{17}$ M. Agus Nuryatno, “Asghar Ali Engineer's Views on Liberation Theology and Womens Issues in Islam", h. 5.

${ }^{18}$ M. Agus Nuryatno, “Asghar Ali Engineer's Views on Liberation Theology and Womens Issues in Islam", h. 5.

${ }^{19}$ Riwayat akademik di jurusan teknik sipil dan bekerja sebagai engineer professional di perusahaan membuat dia digelari sebagai "Engineer".

${ }^{20}$ Hilal Ahmed, "Asghar Ali Engineer 1939-2013”, Economic and Political Weekly, June 2013, Vol XLVIII No 22.

${ }^{21}$ DLitt singkatan dari Doctor of Letters yang diambil dari Bahasa Latin Litterarum Doctor. Gelar ini adalah gelar akademik yang statusnya di atas dari Doktor karena dedikasi dan aktivitasnya yang membela hak-hak kemanusiaan.

${ }^{22}$ http://andromeda.rutgers.edu/ rtavakol/engineer/booklist.htm Website ini dibuat oleh Prof Rahmat Tavakol dari Universitas Rutgers, New Jersey, Amerika. Universitas ini populer dengan basis penelitian yang kuat dan menempati pendidikan tinggi terbaik di New Jersey.
} 
tulisannya dalam bahasa Inggris. Barangkali sebagai strategi agar tulisannya bisa dibaca oleh dunia internasional termasuk Indonesia.

Sebagai seorang aktivis, gagasan-gagasan progresif revolusioner Engineer yang tertuang dalam berbagi teks dijabarkan dalam berbagai aktivitasnya baik dia sebagai pembesar pada Bohras maupun sebagai anak bangsa dalam negara India. Langkah pertama yang Engineer lakukan adalah membentuk dua lembaga yang tidak hanya mendiseminasi ide-ide briliannya tetapi juga mampu membentuk gerakan-gerakan sosial yang mengutamakan harmoni atau perdamaian. Dua lembaga yang dimaksud adalah IIS (Institute of Islamic Studies) yang didirikannya pada 1980 di Mumbai ${ }^{23}$ dan CSSS (Center for Study of Society and Secularism) yang dibentuk pada $1983 .{ }^{24}$ Hanya saja, hasil penelusuran penulis terhadap dua lembaga tersebut disimpulkan bahwa lembaga CSSS saja yang masih aktif dan setiap saat di update kegiatan-kegiatannya. Sementara lembaga yang pertama, IIS, cenderung vakum dari berbagai aktivitasnya dan hanya memuat informasi-informasi sekilas tentang lembaga tersebut. Tujuan utama dari pendirian lembaga CSSS adalah menyebarkan semangat sekularisme and harmonisitas komunal serta perdamaian sosial. Selain itu yang lebih penting adalah CSSS berupaya mengorganisasikan dialog inter-faith dan dialog lintas iman serta keadilan. CSSS ini mirip dengan lembaga Interfidei di Yogyakarta yang juga concern pada dialog lintas iman dan lintas budaya. Bahkan dalam konteks pergerakan sosial Muslim Indonesia, ada beberapa lembaga yang menyerupai CSSS ini. Antara lain Wahid Institute yang dibuat oleh anak-anak muda NU (Nahdhatul Ulama) untuk mendiseminasi ide-ide Abdurrahman Wahid (Gus Dur) serta melakukan gerakan-gerakan sosial dengan misi kemanusiaan dan pluralisme. Sejalan dengan itu, tokoh Muhammadiah serta mantan pimpinan Muhammadiah, Syafii Maarif, juga memiliki lembaga yang sama dengan Wahid Institute, yaitu Maarif Institute yang memiliki visi dan misi pemihakan terhadap nilai-nilai kemanusiaan lewat gerakan-gerakan sosial. Bahkan yang paling populer intelektual Muslim Indonesia, Nurckholis Madjid (1939-2005) yang juga membangun lembaga Paramadina yang tidak hanya dirancang sebagai institusi pendidikan Islam tetapi sekaligus menjadi lembaga yang concern pada pengembangan pluralisme dan multikulturalisme.

\section{Reformulasi Makna Tauhid}

Menurut Engineer, doktrin tauhid menempati posisi sentral dalam Islam. Ia menjadi core dan jantung Islam. Doktrin ini terefleksi pada kalimat lā ilāha illallah (tidak ada Tuhan selain Allah). Kalimat ini tidak hanya melahirkan konsekuensi agama, tetapi juga menyangkut konsekuensi sosio-ekonomi. Nabi Muhammad dalam "mengampanyekan" kalimat lā ilāha illallah tidak hanya menegasikan berhala-berhala

\footnotetext{
${ }^{23}$ Zeenat Shaukat Ali, "The Passing Away of a Legend: A Tribute to Dr Asghar Ali Engineer" Interreligious Insight, Vol VII, Juli, 2013,h.6-7. Lembaga ini bisa dikunjungi melalui website http://ecumene.org/IIS/csss.htm

${ }^{24} \mathrm{CSSS}$ sebagai corong Engineer setiap saat bisa dikunjungi websitenya yang memuat informasi dan updated kegiatan-kegiatannya. Silahkan kunjungi http://www.csss-isla.com/
} 
yang dianggap sebagai tuhan-tuhan masyarakat Arab pada waktu itu, tetapi juga menolak secara tegas pengakuan adanya kekuatan atau otoritas dibalik berhala-berhala tersebut serta kekuasaan yang dibentuk secara sosial dan ekonomi. Yang disebut terakhir seringkali menjadi elemen penting dalam menciptakan penindasan terutama kelompok masyarakat biasa yang tidak memiliki basis ekonomi yang kuat. ${ }^{25}$ Dengan kata lain, menurut Engineer, sebagaimana dikutip oleh Agus Nuryatno, doktrin lā ilāha illallah memiliki dua dimensi yang saling terkait satu sama lain. Dimensi pertama terkait dengan aspek keagamaan atau spiritualitas, sementara dimensi kedua merupakan aspek sosio-politik. Nabi tidak hanya membebaskan masyarakat dari aspek ketuhanan yang menyesatkan tetapi juga membebaskan manusia dari praktek sosial, politik, dan ekonomi yang hegemonik. ${ }^{26}$ Engineer dalam hal ini mengutip pendapat Ahmad Amin, seorang intelektual Mesir yang memberikan penafsiran terhadap kalimat lā ilāha Illallah sebagaimana berikut:

Orang yang berkeinginan memperbudak sesamanya berarti ingin menjadi Tuhan, padahal tiada Tuhan selain Allah; orang yang berkeinginan menjadi tiran, berarti ingin menjadi Tuhan, padahal tiada Tuhan selain Allah; penguasa yang berkeinginan merendahkan rakyatnya berarti ingin menjadi Tuhan, padahal tiada Tuhan selain Allah. Kita menghargai manusia apa pun keadaannya dan darimana pula asalnya, asal bisa menjadi saudara bagi sesamanya... Demokrasi, sosialisme dan keadilan sosial dalam makna yang sesungguhnya akan dan semakin berjaya karena mengajarkan persaudaraan, dan ini merupakan salah satu konsekuensi dari kalimat syahadat, tiada Tuhan selain Allah. ${ }^{27}$

Pandangan Engineer di atas relevan dengan pendapat Ali Syariati bahwa tauhid bukan hanya mengandung prinsip-prinsip pokok dalam Islam seperti iman akan risalah dan Hari Peradilan tetapi tauhid juga melandasi dimensi-dimensi yang lain. Tauhid adalah dasar kehidupan individual dan sosial seorang muslim. Artinya segala kegiatan dan hubungan manusiawi, politik, ekonomi, sastra atau artistik seharusnya tegak di atas titik pusat tauhid. Tauhid memberikan satu arah tunggal, dan ia menjamin kesatuan semangat di antara para penganutnya. ${ }^{28}$ Dengan kata lain, tauhid tidak saja memberikan kepastian, perasaan aman, dan ketenangan batin kepada manusia, ia juga menjadikannya untuk bertanggung jawab terhadap kesejahteraan dirinya dan masyarakat yang lain dengan memberikan arti dan kepada eksistensinya. Tauhid mencakup semua manifestasi keyakinan agama dalam kehidupan spiritual maupun material manusia. ${ }^{29}$

Menurut Engineer, tauhid tidak hanya mengenai keesaan Allah swt sebagaimana pemahaman teologi tradisional, tetapi tauhid juga bermakna kesatuan manusia dalam

\footnotetext{
${ }^{25}$ Agus Nuryatno, “Asghar Ali Engineers View on Liberation Theology”, h. 37.

${ }^{26}$ Agus Nuryatno, "Asghar Ali Engineers View on Liberation Theology", h. 38.

${ }^{27}$ Kutipan langsung dari Asghar Ali Engineer, Islam dan Teologi Pembebasan, h. 11.

${ }^{28}$ Abdul Azis Sachedina, “Ali Syariati, Ideolog Revolusi Iran” dalam John L. Esposito (ed.), Dinamika Kebangunan Islam: Watak, Proses dan Tantangan, terjemahan Bakri Siregar, Voices of Resurgent Islam (Cet. I; Jakarta: Rajawali, 1987), h. 246.

${ }^{29}$ Abdul Azis Sachedina, “Ali Syariati, Ideolog Revolusi Iran”, h. 247.
} 
berbagai hal. Tauhid membentengi manusia dari berbagai bentuk diskriminasi dalam bentuk suku, agama dan ras yang bisa menciptakan manusia terkotak-kotak sehingga manusia kemudian tidak memiliki kesatuan. Dengan kata lain, ada perbedaan stratifikasi sosial yang membuat manusia berada dalam tingkatan-tingkatan kelas. Engineer mengatakan bahwa masyarakat tauhid yang sejati dapat menjamin kesatuan sempurna di antara manusia dan untuk mencapainya perlu membentuk masyarakat tanpa kelas (classless society). Keesaan Allah mengharuskan kesatuan masyarakat (unity of mankind) dengan sempurna, dan masyarakat demikian tidak mentolerir pembedaan dalam bentuk apapun, bahkan pembedaan kelas sekalipun. Tidak akan terjadi solidaritas iman yang sejati kecuali segala bentuk perbedaan suku, agama, kelas dan ras dihilangkan. ${ }^{30}$

Konsep tauhid di atas sangat dekat dengan semangat al-Qur'an untuk mencapai keadilan dan kebajikan ( $a l$-' $a d l u$ wa al-ihsān). Engineer mengutip QS al-Hujurat/49 :13)

Terjemahnya:

Hai manusia, Sesungguhnya Kami menciptakan kamu dari seorang laki-laki dan seorang perempuan dan menjadikan kamu berbangsa-bangsa dan bersuku-suku supaya kamu saling kenal-mengenal. Sesungguhnya orang yang paling mulia diantara kamu disisi Allah ialah orang yang paling taqwa diantara kamu. Sesungguhnya Allah Maha mengetahui lagi Maha Mengenal. ${ }^{31}$

Menurut Engineer, ayat di atas menggambarkan bagaimana mewujudkan keadilan dan kebajikan tidak boleh dilandasi oleh diskriminasi dalam berbagai bentuk. Selama dunia masih terbagi menjadi negara-negara berkembang di satu sisi, dan kelas yang menindas-tertindas di sisi yang lain, kesatuan manusia yang sebenarnya tidak akan mungkin tercapai. Oleh karena itu, tauhid merupakan iman kepada Allah yang tidak bisa ditawar-tawar di satu sisi, dan konsekuensinya adalah menciptakan struktur yang bebas eksploitasi di sisi lain. Sehingga tauhid yang bermakna bagi masyarakat tidak dapat dipisahkan dari dua hal tadi. ${ }^{32}$ Dengan kata lain tauhid yang dimaksudkan dalam teologi pembebasan tidak hanya berakar dari keesaan Tuhan tetapi juga kesatuan masyarakat. Pada titik ini, Engineer berusaha menformulasi tauhid dalam kerangka praktis dan berhubungan langsung dengan realitas kehidupan manusia. Tafsir tauhid ini relevan dengan istilah tauhid sosial yang dimaknai sebagai dimensi praksis dari resiko keimanan kepada Allah Yang Esa. Istilah ini kemudian dikembangkan oleh Syafii Maarif sebagai teologi pemberdayaan masyarakat. Satu teologi yang tidak hanya sibuk mengurus soalsoal yang ghaib tetapi juga memberi atensi terhadap soal-soal kongkret yang terkait dengan realitas sosial. ${ }^{33}$

\footnotetext{
${ }^{30}$ Asghar Ali Engineer, Islam dan Pembebasan, h. 94.

${ }^{31}$ Departemen Agama RI, Al-Qur'an dan Terjemahnya, h. 745.

${ }^{32}$ Asghar Ali Engineer, Islam and Liberation Theology, h. 11-12.

${ }^{33}$ Syafii Maarif, Islam: Kekuatan Doktrin dan Kegamangan Umat (Cet. I; Yogyakarta: Pustaka Pelajar, 1997), h. 3.
} 
Doktrin tauhid yang menegaskan keesaan Allah memerlukan dimensi sosial, politik, ekonomi, iptek dan kebudayaan. Tanpa mengaitkannya dengan dimensi-dimensi tersebut, maka aspek pembebasan dari ketertindasan akan sulit ditemukan. Prinsip egaliter adalah salah satu dimensi sosial dalam doktrin tauhid yang membebaskan manusia dari berbagai bentuk pemasungan dan penindasan terutama kepada kelompok masyarakat yang tidak memiliki power. ${ }^{34}$ Menurut Engineer, dalam konteks teologi pembebasan, tidak hanya aspek sosio-ekonomi yang menjadi tema sentralnya, tetapi juga dibicarakan psiko-sosial. Dalam Islam, dikenal konsep sabar yang seringkali disalahpahami sebagian besar umat Islam. Sabar terkadang diartikan sebagai justifikasi atas ketidakmampuan seseorang untuk melawan penindasan dengan menyerahkan segala urusannya kepada Tuhan. Sabar menjadi keyakinan teologis bahwa segala penindasan yang menimpanya adalah sebuah takdir yang tidak bisa dihindari. Interpretasi tentang sabar inilah yang dimaksud oleh Engineer melanggengkan status quo dan sangat dibenci oleh teologi pembebasan. ${ }^{35}$ Karena salah satu misi teologi menurut Engineer adalah melawan pemerintahan yang memapankan status quo. ${ }^{36}$ Kesabaran itu sendiri dituntut pada saat berjuang untuk melakukan perubahan sosial. Ia menjadi energi positif dalam melakukan perubahan dalam rangka pembebasan bahkan ia bisa menjadi senjata psikologis yang powerful dalam menegakkan tauhid. ${ }^{37}$ Kesabaran inilah yang dimiliki oleh para Nabi dalam menegakkan tauhid keesaan Tuhan dan penciptaan kesatuan masyarakat yang adil. Dalam terminologi Ali Syariati, kesabaran ini adalah "kearifan" atau kebijaksanaan yang menjadi pendorong para nabi dalam menegakkan tauhid serta menjadikannya sebagai reformis moral agung dunia. Tauhid menyempurnakan kesadaran etika dalam manusia. Melalui kearifannya, manusia secara rasional bereaksi terhadap lingkungannya dengan menciptakan tanggung jawab yang diperlukan pada dirinya untuk menghasilkan suatu tatanan sosial yang adil. ${ }^{38}$ Dalam bahasa yang sedikit keras, Ali Syariati mengatakan tauhid atau akidah Islam tidak hanya menjadi "tumpukan informasi ilmiah keagamaan" atau dalam istilah Sayyid Quthb sebagai "terpenjara dalam hati”, tetapi tauhid sejatinya menjadi kekuatan yang bergulat dengan pengalaman historis. ${ }^{39}$

Selain itu, menurut Engineer, dalam tauhid, struktur sosial yang menindas harus diubah sehingga menjadi lebih adil yang tentu saja harus dibarengi dengan perjuangan yang terkadang meminta pengorbanan. ${ }^{40}$ Misi inilah yang dilakukan oleh para nabi dalam membebaskan umatnya dari berbagai belenggu. Perjuangannya tidak hanya terkait dengan reformasi tauhid yang terkait dengan keesaan Tuhan tetapi juga berkaitan dengan misi pembebasan umat dari ketertindasan. Misalnya, Nabi Musa as digambarkan

\footnotetext{
${ }^{34}$ Syafii Maarif, Islam: Kekuatan Doktrin dan Kegamangan Umat, h. 9-10.

${ }^{35}$ Asghar Ali Engineer, Islam and Liberation Theology, h. 12

${ }^{36}$ Asghar Ali Engineer, Islam and Liberation Theology, h. 1-2.

${ }^{37}$ Asghar Ali Engineer, Islam and Liberation Theology, h. 12.

${ }^{38}$ Abdul Azis Sachedina, "Ali Syariati, Ideolog Revolusi Iran”, h. 247.

${ }^{39}$ Afif Muhammad, Dari Teologi ke Ideologi, h. 98.

${ }^{40}$ Asghar Ali Engineer, Islam and Liberation Theology, h. 12
} 
oleh al-Qur'an sebagai pembebas bangsa Israel yang ditindas Firaun. Bangsa Israel sebagai kelompok yang tertindas dan dilemahkan di muka bumi. Nabi Musa adalah seorang pemimpin yang berjuang untuk membebaskan kaumnya dari kelompokkelompok mapan yang menindas. Ia membebaskan dari berbagai macam monopoli dan perbudakan. Nabi Musa secara khusus meminta kepada Firaun untuk menghentikan penindasan dan membiarkan bangsa Yahudi bebas dari berbagai macam bentuk eksploitasi. Perlawanan Nabi Musa kepada Firaun tentu meninggalkan berbagai pengorbanan bagi Nabi Musa sendiri serta bangsa Israel yang terkadang mengancam nyawa mereka. ${ }^{41}$ Selain Nabi Musa as, Nabi Isa as juga disamping berjuang menegakkan tauhid keesaan Tuhan, bentuk pembebasan yang dilakukan adalah menyelamatkan umatnya dari penindasan dalam bentuk perbudakan yang dilakukan oleh bangsa Romawi. Umatnya kemudian menjadi bangsa yang bebas dan terhormat. ${ }^{42}$

Begitu pula Nabi Muhammad saw yang tidak hanya membebaskan manusia dari keberhalaan menuju tauhid keesaan Tuhan tetapi juga melepaskan manusia dari belenggu sosial, budaya dan ekonomi. Penindasan-penindasan tersebut yang terjadi pada masyarakat Mekkah bertalian dengan aspek ketauhidan mereka. ${ }^{43}$ Nabi telah menciptakan masyarakat yang berperadaban berdasarkan kitab suci dari langit, mengajarkan prinsip-prinsip egaliter, keadilan dan kasih sayang terhadap semua. ${ }^{44}$ Artinya, tauhid yang bermakna keesaan Tuhan tidak bisa dilihat secara an sich, tetapi harus dilihat secara komprehensif dengan mengaitkannya dengan dimensi-dimensi lain. Inilah yang dimaksud oleh Ali Syariati sebagai nidhām al-tauhīd (sistem yang berdasarkan kesatuan). ${ }^{45}$

Singkatnya, menurut penulis, Engineer telah menjadikan tauhid sebagai titik episentrumnya. Tauhid menjadi sentra dari semua persoalan yang ada dalam Islam. Hal ini tampak bagaimana Islam pertama kali menyapa masyarakat Arab dengan misi penegakan tauhid. Ayat yang pertama kali turun sangat jelas membenarkan pernyataan tersebut. Ini juga menjadi misi prioritas Nabi Muhammad dalam rangka memperbaiki tatanan ketauhidan masyarakat Arab pada waktu itu yang masih diliputi oleh tradisi animisme dan politeisme serta menata ulang praktek ekonomi yang dikuasai oleh para kapitalis-kapitalis masyarakat Arab pada waktu itu. Dalam konteks ini, Engineer kemudian merekonstruksi makna Allāhu Akbar yang tidak hanya melambangkan "supremasi" Tuhan terhadap segala sesuatu, tetapi Allāhu Akbar juga bermakna bahwa seseorang tidak boleh melakukan praktek dominasi dan hegemoni terhadap orang lain karena semua manusia sama di hadapan Allah swt. ${ }^{46}$ Dengan kata lain, praktek diskriminasi dalam berbagai hal melanggar makna Allāhu Akbar yang mengisyaratkan

\footnotetext{
${ }^{41}$ Lihat Gamal al-Banna, Relasi Agama dan Negara (Cet.I; Jakarta: Tim Mataair Publishing, 2006), h. 337. Lihat juga Asghar Ali Engineer, Islam dan Pembebasan, h. 96.

${ }^{42}$ Lihat Gamal al-Banna, Relasi Agama dan Negara, h. 337.

${ }^{43}$ Asghar Ali Engineer, Islam and Liberation Theology, h. 41.

${ }^{44}$ Lihat Gamal al-Banna, Relasi Agama dan Negara, h. 337.

${ }^{45}$ Abdul Azis Sachedina, "Ali Syariati, Ideolog Revolusi Iran”, h. 247.

${ }^{46}$ Agus Nuryatno, "Asghar Ali Engineers View on Liberation Theology", h. 42.
} 
Allah sebagai Yang Maha Besar. Tafsir Engineer terhadap makna Allāhu Akbar ini tentu saja sangat revolusioner. Efek yang dilahirkan dari makna tersebut tidak hanya menegaskan kepada kesucian dan kemahabesaran Tuhan, tetapi juga berdampak kepada penguatan aturan dalam kohesi sosial bahwa tidak boleh ada kelas-kelas sosial yang melahirkan diskriminasi. Sekali lagi tampak bagaimana Engineer selalu ingin menempatkan teologi dalam konteks kemanusiaan. Terkait dengan hal tersebut, menarik untuk menyimak uraian berikut yang mencoba mengelaborasi Iman sebagai formulasi teologi humanis yang menjadi inti dari teologi pembebasan.

Engineer mengatakan bahwa untuk menciptakan tauhid yang hakiki, seseorang harus memiliki landasan iman yang kuat. Hanya saja iman dalam perspektif Engineer tidak sederhana sebagaimana yang dipahami pada umumnya. Iman tidak hanya sekedar mempercayai Tuhan, tetapi iman menurutnya melandasi perjuangan yang keras dalam upaya menciptakan masyarakat yang berkeadilan. Sesuai dengan namanya, iman berasal dari bahasa Arab yang merupakan derivasi dari kata àmana yang artinya selamat, damai, perlindungan, dapat diandalkan, terpercaya dan yakin. Menurut Engineer, iman yang sebenarnya akan mengimplikasikan semua hal-hal tersebut. Dengan kata lain, orang yang beriman pasti dapat dipercaya. Tanpa dilatarbelakangi dengan iman, katakata dan gagasan hanya akan berarti bagi dirinya sendiri. Engineer dalam hal ini terkontaminasi oleh ide Erich Fromm yang mengatakan bahwa "kata dan pola pikir itu berbahaya karena akan memperbudak orang lain karena bisa dengan mudah berubah menjadi kekuasaan yang disembah padahal kehidupan harus bersandar pada kebenaran." Di sinilah peran iman yang bisa membuat kata dan pola pikir menjadi bermanfaat, bukannya menjadi struktur yang menindas. Orang yang beriman juga berusaha menciptakan kedamaian dan ketertiban, dan memiliki keyakinan terhadap semua nilainilai kebaikan dalam kehidupan. ${ }^{47}$ Disinilah peran tauhid dalam memantapkan keimanan seseorang.

Jika dibuka lembaran sejarah teologi Islam klasik, maka konsep iman telah menjadi bahan diskusi dan perdebatan di antara mereka. Bagi kalangan teologi muktazilah, iman bukanlah tasdīq (membenarkan), bukan pula ma'rifah tetapi iman adalah melaksanakan perintah-perintah Tuhan. Perintah Tuhan yang dimaksud di sini bukan hanya yang terkait dengan kewajiban tetapi juga yang bersifat sunnat. Dengan kata lain, muktazilah menempatkan efek dari keimanan kepada Tuhan yaitu perbuatan menjadi inti dari iman. Ia menjadi entitas penting dari iman karena ia adalah wujud dari keimanan. ${ }^{48}$ Muktazilah tidak ingin memisahkan antara iman dan amal. Keduanya harus saling berkait kelindan. ${ }^{49}$ Lain lagi dengan teologi Asy'ariah, iman bukanlah amal atau ma'rifah, tetapi iman adalah tasdīq. Menurut teologi ini, manusia dapat mengetahui

\footnotetext{
${ }^{47}$ Asghar Ali Engineer, Islam dan Teologi Pembebasan, h. 12.

${ }^{48}$ Keterkaitan antara iman dan amal shaleh dapat dilihat dalam beberapa ayat dalam al-Qur'an. Antara lain QS Ali Imran/03:57 ; QS an-Nisa/04: 57 ; QS Hud/11:23; QS al-A'raf /07:42; QS alMaidah/05:07. Semua ayat ini menunjukkan bagaimana iman dan amal perbuatan menjadi satu elemen yang tidak bisa dipisahkan.

${ }^{49}$ Harun Nasution, Teologi Islam, h. 147.
} 
kewajiban itu hanya melalui wahyu. Wahyulah yang mengatakan dan menerangkan kepada manusia, bahwa ia berkewajiban mengetahui Tuhan, dan manusia harus menerima kebenaran berita ini. Oleh karena itu, teologi ini memahami bahwa iman adalah tasdīq bi Allah. Tasdīq tentang adanya Tuhan, rasul-rasul dan berita yang mereka bawa. Tasdīq ini tidak sempurna jika tidak disertai dengan pengetahuan. Hanya saja pengetahuan ini tidak timbul kecuali dengan bantuan wahyu. ${ }^{50}$

Senada dengan Asy'ariah, teologi Maturidiah golongan Bukhara juga berpendapat bahwa akal tidak dapat sampai kepada kewajiban mengetahui adanya Tuhan, iman tidak bisa mengambil bentuk ma'rifah atau amal sebagaimana pendapat Muktazilah, tetapi iman merupakan tasdīq. Iman menurut teologi ini adalah menerima dalam hati dengan lidah bahwa tidak ada Tuhan selain Allah dan bahwa tidak ada yang serupa dengan Dia. Hal yang berbeda dengan teologi Maturidiah golongan Samarkand yang menganggap bahwa akal dapat mengetahui kewajiban mengetahui Tuhan. Teologi ini mengatakan bahwa Iman adalah mengetahui Tuhan dan ketuhanan-Nya, ma'rifah adalah mengetahui Tuhan dengan segala sifatnya dan tauhid adalah mengenal Tuhan dalam keesaan-Nya. Teologi ini berkeyakinan bahwa iman harus melebihi tasdīq yaitu iman dan amal. ${ }^{51}$

Merujuk kepada perbedaan teologi di atas tentang konsep iman, penulis memandang bahwa iman perspektif Engineer lebih dekat dengan konsep Muktazilah yang menekankan pada amal atau perbuatan manusia yang merupakan konsekuensi dari iman. Selain pengaruh Muktazilah, Engineer juga terpengaruh oleh Sayyid Quthb yang juga mengatakan bahwa pengakuan atas Allah sebagai Tuhan belumlah disebut iman, tetapi baru merupakan wujud dari iqrār. Ia masih harus disertai dengan pembuktian dalam bentuk ketundukan terhadap syariat yang ditetapkan-Nya. Itu pula sebabnya ketika manusia diturunkan ke dunia sebagai khalifah Tuhan, disitu perjanjian dengan Tuhan diperbarui dengan menambahkan syarat bahwa pengakuan atas ketuhanan Allah mesti disertai dengan mengikuti petunjuk-Nya. Petunjuk inilah yang disebut oleh Sayyid Quthb sebagai manhaj atau pedoman. ${ }^{52}$

Terkait pemikiran modern Islam, pendapat ini selaras dengan apa yang dikatakan oleh Farid Esack (1.1959), sebagaimana dikutip oleh Agus Nuryatno, melihat bahwa iman paling tidak memiliki tiga interpretasi yang berbeda. Pertama, iman itu dipergunakan untuk menegaskan keesaan Tuhan, meyakini adanya hari kiamat dan kenabian Muhammad saw. Kedua, iman juga bisa dijabarkan dalam konteks kehidupan masyarakat Islam, dan ketiga, iman adalah perjuangan yang berlangsung terus-menerus untuk membumikan ketauhidan dalam konteks perbuatan manusia. ${ }^{53}$

Menurut Engineer, iman tidak hanya berimplikasi kepada hal-hal yang bersifat metafisik, tetapi iman juga berefek kepada konsekuensi-konsekuensi sosial

\footnotetext{
${ }^{50}$ Harun Nasution, Teologi Islam, h. 148.

${ }^{51}$ Harun Nasution, Teologi Islam, h. 148.

${ }^{52}$ Sayyid Quthb, Fì Zhilāl al-Qur'an (Juz VII; Beirut Dar al-Syuruq, 1980), h. 836.

${ }^{53}$ Agus Nuryatno, "Asghar Ali Engineers View on Liberation Theology”, h. 42.
} 
kemasyarakatan. Ia mengatakan bahwa orang-orang yang mengaku beriman kepada Allah dan menunjukkan kesalehan mereka tetapi mencabut hak-hak anak yatim dan orang miskin bukanlah mukmin sejati. Untuk menjadi mukmin sejati, menurut Engineer, seseorang harus turut memberikan andil terhadap pembentukan masyarakat yang adil dengan jalan memelihara anak yatim, orang-orang yang tertindas, dan orangorang yang terpinggirkan. Dalam tradisi teologi Islam pada abad pertengahan, para teolog-teolog menekankan pentingnya pemberian sedekah, tetapi dalam masyarakat modern, teologi pembebasan harus menginterpretasikannya dalam model pemberian sarana untuk membentuk suatu struktur sosial yang demokratik, dengan menekankan distribusi yang sama dari semua sumber yang tersedia. ${ }^{54}$

Rekonstruksi makna iman yang menjadi landasan tauhid di atas juga berimplikasi kepada redefinisi makna kāfir sebagai antonim dari iman. Käfir dalam perspektif Engineer, tidak hanya bermakna ketidakpercayaan religius, seperti pemahaman teologi tradisional, tetapi secara tidak langsung juga menyatakan perlawanan dan penentangan terhadap terhadap sistem dan masyarakat yang adil dan egalitarian serta menjadi bagian dari bentuk penindasan dan eksploitasi. ${ }^{55}$ Jadi, orangorang käfir adalah orang yang tidak percaya kepada Allah dan secara aktif menentang usaha-usaha yang jujur untuk membentuk kembali masyarakat, penghapusan penumpukan kekayaan, penindasan, eksploitasi dan segala bentuk ketidakdilan. Menurut Engineer meskipun seseorang secara formal beriman kepada Allah, tetapi tetap menjalani kehidupan materialistik dan hedonistik dan membiarkan orang-orang lain di sekitarnya hidup dalam ketertindasan maka menurut Engineer, orang tersebut masih tergolong orang-orang kāfir. Engineer dalam hal ini merujuk kepada QS al-Mā'un/107: $1-7^{56}$

Terjemahnya:

Tahukah kamu (orang) yang mendustakan agama? Itulah orang yang menghardik anak yatim, dan tidak menganjurkan memberi makan pada orang miskin. Maka kecelakaanlah bagi orang-orang yang shalat, (yaitu) orang-orang yang lalai dari shalatnya, orang-orang yang berbuat riya dan untuk mencari pujian atau kemasyhuran di masyarakat. ${ }^{57}$

Ayat-ayat di atas mengisyaratkan bagaimana agama yang di dalamnya ada keimanan harus memiliki perhatian yang besar terhadap realitas sosial di sekitarnya. Barometer keimanan seseorang diukur sejauh mana kepeduliannya terhadap persoalan sosial kemasyarakatannya. Semakin tinggi tingkat kepedulian seseorang terhadap sesamanya, maka kualitas keimanannya juga semakin tinggi. Hal ini berarti bahwa Islam tidak hanya mengajarkan kehidupan dan kenikmatan personal, tetapi sangat menekankan pentingnya menjaga kehidupan sosial dengan cara membebaskan mereka

\footnotetext{
${ }^{54}$ Asghar Ali Engineer, Islam dan Pembebasan, h. 90.

${ }^{55}$ Asghar Ali Engineer, Islam dan Teologi Pembebasan, h. 178.

${ }^{56}$ Ayat ini turun di Mekkah sebagai respon terhadap model kehidupan masyarakat Arab pada waktu itu yang dikuasai oleh kapitalis-kapitalis yang tidak berlandaskan kehidupan egalitarian.

${ }^{57}$ Departemen Agama RI, Al-Qur'an dan Terjemahnya, h. 917.
} 
dari berbagai bentuk penindasan terutama belenggu ekonomi. Menurut Engineer, ayatayat di atas adalah salah satu contoh bagaimana al-Qur'an sangat mendukung teologi pembebasan, bahkan inspirasi teologi pembebasan itu sendiri berasal dari semangat alQur'an. Membantu orang-orang miskin serta menjaga anak-anak yatim adalah salah satu bentuk pembebasan yang hanya bisa dilakukan oleh orang-orang beriman. ${ }^{58}$ Orangorang yang tidak berjuang untuk membebaskan orang-orang yang tertindas dan lemah, menurut Engineer, tidak bisa dikategorikan sebagai orang beriman meskipun sudah beriman secara verbal. Bahkan dalam bahasa yang lebih tegas, Sayyid Quthb mengatakan bahwa meskipun seseorang beribu kali mengatakan dirinya mukmin, namun jika pengakuannya tidak disertai dengan amal, maka dia bukanlah seorang mukmin. Akidah menurut Quthb bukanlah sesuatu yang terpenjara dalam hati atau tersimpan di peti intelektualisme. ${ }^{59}$ Akidah, menurut Engineer, adalah gerakan perubahan atau pembebasan. Engineer dalam hal ini mengutip salah satu ayat dalam QS al-Ankabūt/29: 2

Terjemahnya:

Apakah manusia itu mengira bahwa mereka dibiarkan (saja) mengatakan: "Kami telah beriman", sedang mereka tidak diuji lagi? ${ }^{60}$

Ayat di atas menurut Engineer, menerangkan bahwa iman seseorang itu harus diuji dengan perjuangan. Dibutuhkan perjuangan yang keras melawan penindasan. Ia menuntut setiap muslim untuk berjuang menghadapi eksploitasi dan penindasan, baik di negara mereka sendiri maupun di negara lain melalui kerjasama dengan seluruh kekuatan imperialis. ${ }^{61}$ Pada titik ini, tampak bagaimana Engineer ingin menempatkan iman berjalan seiring dengan jihad atau perjuangan. Ia mengutip salah satu hadis yang berbunyi:

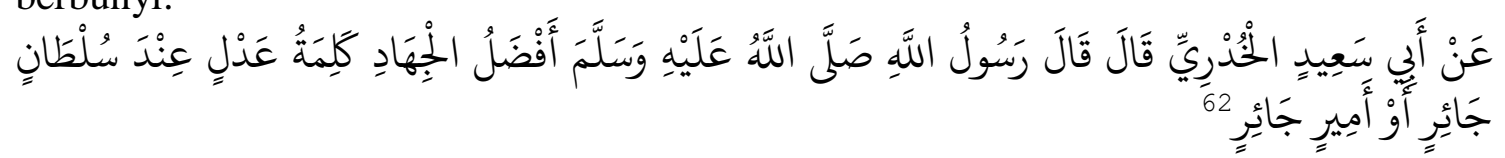

Artinya:

Bentuk terbaik dari jihad adalah menyampaikan kebenaran di hadapan para penguasa yang tiran.

Hanya saja, jihad yang dimaksud oleh Engineer berbeda dengan pemahaman kelompok radikal-ekstremis. ${ }^{63}$ Ia mengatakan bahwa meskipun jihad secara literal

\footnotetext{
${ }^{58}$ Asghar Ali Engineer, Islam dan Pembebasan, h. 97.

${ }^{59}$ Sayyid Quthb, F̄̄ Zhilāl al-Qur'an (Juz XI; Beirut: Dar al-Syuruq, 1980), h. 1734.

${ }^{60}$ Departemen Agama RI, Al-Qur'an dan Terjemahnya, h. 559.

${ }^{61}$ Asghar Ali Engineer, Islam dan Pembebasan, h. 97.

${ }^{62}$ Imam Abi Daud, Sunan Abi Daud dalam program Lidwa Hadis, Lidwa Pusaka Software, t.th, hadis no 3781 .

${ }^{63}$ Jihad menurut Greg Fealy terbagi kepada dua yaitu jihad kecil dan jihad besar. Jihad kecil adalah perjuangan personal menuju kehidupan spiritual yang sempurna, sedangkan jihad yang kedua melibatkan segala sesuatu yang essensial, melalui kegiatan dakwah hingga sampai kepada perang suci. Jihad kedua ini dipakai oleh para kelompok muslim ekstremis untuk menjustifikasi perjuangan mereka dalam memerangi Amerika dan sekutu-sekutunya yang mereka istilahkan dengan Holy War (perang suci). Uraian lebih lanjut, lihat Greg Fealy, Anthony Bubalo, Joining the Caravan?: The Middle East, Islamism
} 
bermakna berjuang, tetapi Engineer menfokuskan pada perjuangan melawan eksploitasi, korupsi, dan penindasan dalam berbagai bentuknya. Dengan kata lain, teologi pembebasan tidak menyukai sikap diam dan apatis terhadap berbagai bentuk penindasan. Semua bentuk penindasan tersebut harus dilawan dengan gerakan jihad atau perjuangan. Menurut Ziauddin Sardar (1.1951), jihad berarti melawan penindasan, despotisme dan ketidakadilan demi kepentingan yang tertindas terlepas dari agama dan strata sosialnya. Namun menurut Sardar, perjuangan atas keadilan hanyalah salah satu aspek jihad, karena seperti berbagai konsep Islam lainnya, jihad harus dilakukan pada berbagai level. ${ }^{64}$ Jika merujuk kepada sarjana Islam klasik, seperti Ibnu Taimiyah (1263-1328), sebagaimana dikutip oleh Sardar, jihad bisa dilakukan dengan tiga cara, yaitu lewat hati, lidah dan tangan. Jihad hati atau perjuangan melawan kelemahan dan kejahatan batinnya sendiri sering disebut sebagai jihad terbesar sebagaimana nabi menyebutnya setelah pulang dari Perang Badar. Sementara jihad lidah dan tangan membutuhkan pemahaman dan kesabaran. ${ }^{65}$

Potensi untuk berjihad mutlak dimiliki oleh setiap manusia. Hal tersebut terkandung pada makna beriman kepada yang gaib. ${ }^{66}$ Menurut Engineer, keimanan tersebut perlu ditafsirkan dengan semangat pembebasan. Keimanan kepada yang ghaib berarti meyakini bahwa ada suatu potensi yang tak terbatas yang belum diaktualisasikan dan tidak terlihat. Potensi ini tersimpan di alam semesta, yaitu di dalam dan di luar diri manusia. Oleh karena itu, manusia harus yakin bahwa dirinya mampu mengembangkan potensi-potensi dan kreativitas yang terletak dalam dirinya dan tersembunyi dari pandangan umum. ${ }^{67}$

Interpretasi Engineer di atas terkait iman kepada yang gaib mengilustrasikan bagaimana teologi pembebasan menghendaki adanya perjuangan atau gerakan dari orang-orang beriman. Bagi Engineer, teologi-teologi yang berorientasi pada perjuangan (struggle oriented), pesimisme dan keputusasaan dianggap sebagai dosa. Al-Qur'an memerintahkan orang-orang yang beriman agar berkeyakinan, berjuang melawan ketidakdilan dan agar tidak berputus asa serta bersikap pasrah. Poin ini menjadi entitas penting dalam tauhid. ${ }^{68}$ Dalam konteks ini, Hasan Sho'ub, intelektual Libanon, menyebutnya sebagai iman yang mutlak yang menerima potensi manusia yang diwujudkan melalui berbagai perubahan atau perjuangan dalam kerangka ekonomi dan sosial. Keyakinan bahwa manusia memiliki potensi menjadi pijakan dasar bagi manusia untuk melakukan gerakan perubahan sehingga tidak menciptakan kegersangan iman yang kreatif, kegersangan rasio yang paradigmatik, kegersangan indera alternatif yang

and Indonesia, diterjemahkan oleh Akh Muzakki, Jejak Kafilah: Pengaruh Radikalisme Timur Tengah di Indonesia (Cet.I; Bandung: Mizan, 2007), h. 46.

${ }^{64}$ Ziauddin Sardar, Jihad Intelektual: Merumuskan Parameter-Parameter Sains Islam, terj. AE Priyono (Cet.I; Surabaya: Risalah Gusti, 1998), h. 20.

${ }^{65}$ Uraian lebih lanjut lihat Ziauddin Sardar, Jihad Intelektual, h. 21.

${ }^{66} \mathrm{QS}$ al-Baqarah/2: 3.

${ }^{67}$ Asghar Ali Engineer, Islam and Liberation Theology, h. 14.

${ }^{68}$ Pendapat Engineer ini didasari atas pemahamannya atas QS ali Imran /3: 139 ; QS Ali Imran/3: 146. 
selektif, dan kegersangan estetika. ${ }^{69}$ Kegersangan inilah yang menjadi biang kerok dari kemusnahan iman yang berimplikasi kepada terciptanya manusia-manusia pesimis dan cepat berputus asa. Memang di dalam Islam terkandung makna kepasrahan, tetapi bukan berarti pada penghambaan pada kepasrahan, bukan pula fatalisme dan keterbelengguan, juga bukan diam dan mengekor saja. Islam memiliki makna kebebasan dan disiplin, pembangunan dan pembebasan, gerakan dan kreativitas. Bahkan tujuan paripurna diturunkannya wahyu dalam Islam adalah pembebasan manusia tertindas untuk membangun dunia ini dalam perspektif yang baru. $^{70}$

\section{Kesimpulan}

Uraian di atas menggambarkan bagaimana Engineer mereformulasi makna tauhid yang awalnya hanya bersifat ritual-normatif menuju kepada lahirnya gerakan. Tauhid tidak hanya membicarakan tentang Tuhan, serta aspek-aspek yang berhubungan dengan-Nya, tetapi tauhid mampu melahirkan gerakan kemanusiaan. Keberpihakan Engineer kepada kelompok tertindas menjadikan makna tauhid sebagai konsep yang imanen dan inheren dalam kehidupan manusia. Tauhid yang kuat menjadi benteng manusia untuk menangkal dan melawan berbagai bentuk penindasan dan eksploitasi. Tauhid yang di dalamnya ada iman juga melahirkan gerakan aktif dari orang-orang beriman yang tidak hanya berhenti pada tataran teoretis atau verbal, tetapi iman telah menggiring orang-orang beriman untuk menjadi aktif dalam berbagai bentuk perubahan terutama membela orang-orang yang tertindas sehingga mereka memiliki kebebasan dan kemerdekaan. Pendapat Engineer ini didasari atas keyakinannya bahwa iman tidak sekedar membenarkan, atau mengetahui sesuatu tetapi yang paling penting adalah konsekuensi dari iman itu adalah amal atau perbuatan. Dari perbuatan inilah, gerakangerakan perubahan dan keberpihakan kepada kelompok-kelompok tertindas lahir dan membuat iman menjadi sangat humanis. Inilah yang dimaksud oleh penulis sebagai tauhid humanis yang merupakan inti dari ajaran Islam yang tidak hanya memperbincangkan aspek-aspek keimanan kepada Tuhan tetapi intinya adalah memperjuangkan nilai-nilai kemanusiaan yang berlandaskan iman kepada Tuhan serta membebaskan manusia dari berbagai belenggu sosial, politik, dan budaya. Gerakangerakan tersebut berakhir pada terciptanya keadilan yang bisa dirasakan oleh manusia.

\section{DAFTAR PUSTAKA}

Abdullah, Amin. Falsafah Kalam di Era Post-modernisme. Yogyakarta: Pustaka Pelajar; 1997.

Ahmed, Hilal. "Asghar Ali Engineer 1939-2013”, Economic and Political Weekly, June 2013, Vol XLVIII No 22.

Ali, Zeenat Shaukat. "The Passing Away of a Legend: A Tribute to Dr Asghar Ali Engineer" Interreligious Insight, Vol VII, Juli, 2013.

\footnotetext{
${ }^{69}$ Hasan Sho'ub, Islam dan Revolusi Pemikiran, h. 24-25.

${ }^{70}$ Hasan Sho'ub, Islam dan Revolusi Pemikiran, h. 26.
} 
Amaladoss, Michael. Life in freedom: Liberation Theologies from Asia. diterjemahkan oleh A Widyamartala dan Cinderalas, Teologi Pembebasan Asia. Yogyakarta: Pustaka Pelajar, 2000.

Arkoun, Muhammad. "Reading the Religious Text: A New Approach", http://www.Islam21/keyissues/modernist.

Banna, Gamal al- Relasi Agama dan Negara. Cet.I; Jakarta: Tim Mataair Publishing, 2006.

Bubalo, Greg Fealy, Anthony. Joining the Caravan?: The Middle East, Islamism and Indonesia, diterjemahkan oleh Akh Muzakki, Jejak Kafilah: Pengaruh Radikalisme Timur Tengah di Indonesia. Cet.I; Bandung: Mizan, 2007.

Effendi, Johan. "Memikirkan Kembali Asumsi Pemikiran Kita" Kata Pengantar buku Asghar Ali Engineer, Islam and Its Relevance to Our Age, diterjemahkan oleh Hairus Salim HS dan Imam Baehaqy, Islam dan Pembebasan. Yogyakarta: LKiS, 1993.

Engineer, Asghar Ali. The Bohras. Delhi: Vikas Publishing, 1980.

"Reconstruction of Islamic Thought" http://andromeda.rutgers.edu / rtavakol/engineer/recon.htm13. diakses pada tanggal 13 Maret 2015.

Islam and Liberation Theology : Essays on Liberative Elements in Islam. New Delhi: Sterling Publishers Limited, 1990.

"A New Approach of Islam Needed" http://andromeda.rutgers.edu / rtavakol/engineer/recon.htm13 (diakses pada tanggal 07 April 2015).

. "Islam and Human Rights" dalam Azhar Arsyad (et al), Islam and Global Peace. Cet. I; Yogyakarta: Madyan Press, 2002.

"Reconstruction of Islamic Thought"

http://andromeda.rutgers.edu / rtavakol/engineer/recon.htm13 (diakses pada tanggal 06 April 2015.

Society and Secularism. Mumbai. h.2

. "The Concept of Compassion in Islam", GRV, July-October, Vol.2/I-II.

"Understanding the Quran", Tribune Business News. Washington. 10 Februari, 2012.

"What I Believe" http://andromeda.rutgers.edu / rtavakol/engineer/recon.htm13. diakses pada tanggal 14 Maret 2015. Islam and Its Relevance to Our Age. diterj. Oleh Hairus Salim HS dan Imam Baehaqy, Islam dan Pembebasan. Yogyakarta: LKiS, 1993. On Developing Theology of Peace in Islam, diterjemahkan oleh Rizqon Hamami. Liberalisasi Teologi Islam: Membangun Teologi Damai dalam Islam. Cet. I; Yogyakarta: Alenia, 2004. 
The Origin and Development of Islam: A Essay on its SocioEconomic Growth. Bombay: Orient Longman Ltd, 1980.

Gutierrez, Gustavo. A Theology of Liberation; History, Politics and Salvation. terj. C. India dan John Eagleeson 1971. Maryknoll: Orbis Books, 1973.

. Dirasah Islamiah, diterjemahkan oleh Miftah Faqih, Islamologi I: Dari Teologi Statis ke Anarkis. Yogyakarta: LKiS, ;Cet. II, 2004.

Latif, Muhaemin. Islamologi Terapan: Membongkar Bangunan Pemikiran Islam ala Mohammed Arkoun. Cet. I: Makassar: Alauddin University Press, 2012. . Muhammad Shahrur dan Dekonstruksi Pembacaan Terhadap alQur'an. Cet. I;Makassar: Alauddin University Press, 2011.

Maarif, Syafii. Islam: Kekuatan Doktrin dan Kegamangan Umat. Cet. I; Yogyakarta: Pustaka Pelajar, 1997.

Malaky, Ekky. Dari Sayyid Qutub, Ali Syariati, The lord of the Rings hingga ke Bollywood. Cet. I: Jakarta; Lentera, 2004.

Muslim, Imam. Shahih Muslim, dalam program Lidwa Hadis, Lidwa Pusaka Software, t.th, hadis no. 2862.

Nasution, Harun. Teologi Islam: Aliran-Aliran Sejarah Analisa Perbandingan. Cet. V: Jakarta: UI Press, 2009.

Nuryatno, M Agus. “Examining Asghar Ali Engineer's Qur'anic Interpretation of Women in Islam", al-Jamiah Vol.45, No. 2. 2007.

. “Asghar Ali Engineer's Views on Liberation Theology and Womens Issues in Islam" Theses unpublished, Canada: Mc.Gill Montreal, 2000 .

"Examining Asghar Ali Engineer's Quranic Interpretation of Woman in Islam”, Jurnal al-Jamiah, Vol 45, No. 2, 2007 M/1428 H.

Quthub, Sayyid. Islam: the Misunderstood Religion. diterj. oleh Fungky Kusnaedy Timur, Islam Agama Pembebas. Yogyakarta: Mitra Pustaka; Cet. I, 2001.

Sachedina, Abdul Azis. "Ali Syariati, Ideolog Revolusi Iran” dalam John L. Esposito (ed.), Dinamika Kebangunan Islam: Watak, Proses dan Tantangan, terjemahan Bakri Siregar, Voices of Resurgent Islam. Cet. I; Jakarta: Rajawali, 1987.

Sardar, Ziauddin. Jihad Intelektual: Merumuskan Parameter-Parameter Sains Islam, terj. AE Priyono. Cet.I; Surabaya: Risalah Gusti, 1998.

Shahrur, Muhammad. al-Kitab wa al-Qur'an; Qiraah Muashirah. Damaskus: al-Ahali al-Thibaah, 1990.

Sho'ub, Hasan. Al-Islam wa Tahaddiyatul 'Ashri, terj. Muhammad Luqman Hakim, Islam dan Revolusi Pemikiran. Cet. I; Surabaya: Risalah Gusti, 1997.

Taib, Mohammad Imran Mohamed. "Religion, Liberation and Reforms: An Introduction to the Key Thoughts of Asghar Ali Engineer" Indian Journal of Secularism. Vol 10. No 3. Oct-Des 2006. 